\title{
Digitization, creativity, and diversification: A worldview followed by an application in architecture and urbanism
}

\section{Authors}

Dan C. Baciu, ${ }^{1}$ Diana Della Pietra. ${ }^{2}$

Faculty of Architecture and the Built Environment, TU Delft, Delft, Netherlands.

\section{Abstract}

This article summarizes the author's past research and reports empirical evidence to support the hypothesis that cycles of growth and diversification exist in urban space.

\section{Digitization, creativity, and diversification}

A, B, C, ... there are some thirty letters to the alphabet, more than a million to this volume of Igloo, and an unknown number in the range of quadrillions of letters has been written down since the alphabet was invented, only three thousand years ago. What may have at first been a handful of straight and curvy symbols has become a world of limitless possibilities.

There's an interesting twist to this edgy and curvy story of writing. Early alphabets were edgy, with many straight and few curved lines. The Latin letters, which came later, have a much more even distribution of straight and curved lines. Roughly half of the letters are composed of straight lines, while the other half also contains curved lines. One could decide to replace the curved lines with zeroes, and the straight lines with ones; and one could rewrite all letters as combinations of just zeroes and ones. Well, one would then get an alphabet of just zeroes and ones, which-surprise-is a binary code like the one used in computers. Computer codes are codes of zeroes and ones.

Some people picture computers as rigorous machines that cannot make errors. In reality, computers cannot be separated from humans, and this is what makes them powerful. One of the things that computers and humans share is that they work with

\footnotetext{
1 https://orcid.org/0000-0002-0043-5616

2 https://orcid.org/0000-0001-7373-8901
} 
digital systems. The digital systems, such as the alphabet and the 0-1 computer code, have one truly fabulous characteristic that makes both computers and humans powerful. That's the characteristic we have already observed. With only a handful of symbols, digital systems open up a world of limitless possibilities. It's easy to see. With only the fingers on one hand, one can count, count, and count, and we haven't yet grown tired of counting. This opens up room for creativity and diversification. One can learn to count new things.

Maybe this phenomenon, namely that digital systems open up room for creativity and diversification, is best seen in the genetic code. With just two base pairs-one could have decided to call them zero and one-the genetic code encodes for any genetic information. Uncountable zillions of genetic base pairs have been written since the beginning of life on earth; and we haven't yet grown tired of life all together. The creativity and diversity of biological life will convince any doubter that systems of just zeroes and ones have limitless potential.

And there is more. Genetic base pairs are chemical compounds, which are combined out of atoms. Yet, these atoms, when it comes to their type and properties, are determined by their kernels, which are combinations of protons and neutrons. In turn, the protons and neutrons are combinations of quarks. There are only two types of quarks: up and down quarks. One could have decided to call these quarks zero and onequarks. The quarks make up the binary code of the universe. The universe we live in is a digital universe. This digital universe has opened up endless possibilities for creativity and diversification. Think just how diverse ecosystems and cities are. They are oases of diversity, all rooted in binary codes.

In my previous article of Igloo, I have spoken about the replicator-mutator-equation, but I haven't showed the equation. This time, I would like to do this. You can see the equation, playfully annotated in Figure 1 . The equation states that new culture is the reproduction of past culture, transformed by creativity and interplay. Interplay is very important because it may lead to diversification. To stress this fact, I took the liberty to write that new culture is the reproduction of past culture, transformed by creativity, and diversification.

Let me now explain why this equation goes hand in glove with digital systems. First, digital systems start with just a handful of symbols. This economy of means makes reproduction easy, and reproduction is part of the equation. The easier reproduction is, the better. Next, digital systems make it possible to creatively combine and recombine symbols, which gives rise to creativity. Creativity, once again, is part of the equation. Finally, digital systems open up limitless worlds of possibilities. Diversification is necessary to broadly explore what is possible. In order to explore things as broad as the ocean, you need multiple ships to sail in multiple directions. Figuratively, that's what diversification is. Diversification is necessary when exploring oceanwide worlds of possibilities. It is evident than, that-if evolution advances through reproduction, creativity, and diversity, as modeled with the replicator-mutator-equation-our universe should be full of digital systems; and this it is indeed. We live in a limitless and digital universe. 


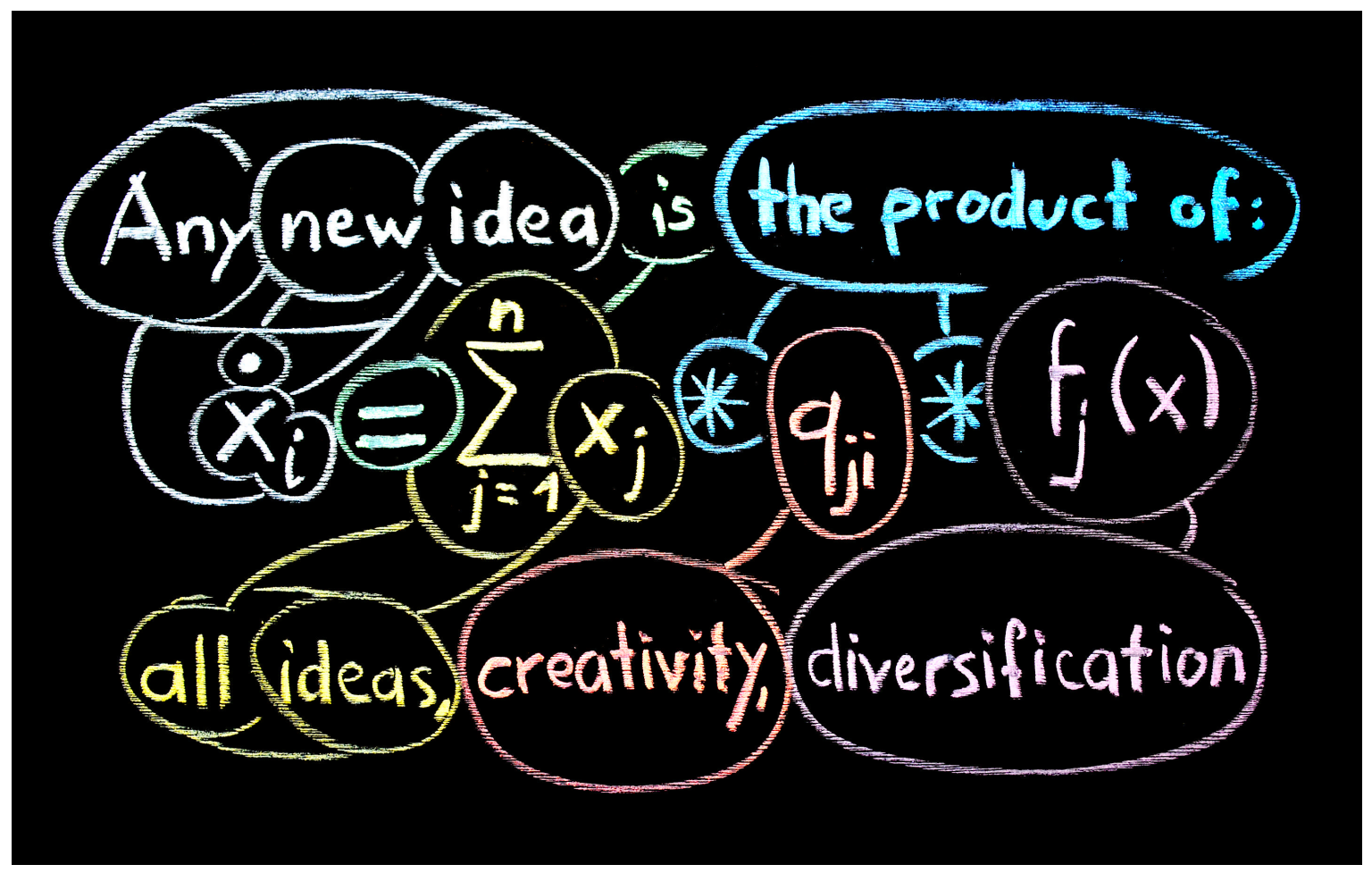

Figure 1. Any new idea is the product of all past ideas, creativity, \& diversification. Technically, the term $q_{i j}$ stays for any creativity matrix, mutation matrix, or association matrix. This term is also used in the quasispecies equation. The term $f_{i}(\mathrm{x})$ stays for the interplay between diverse variants.

For me, this insight is a worldview. It is a digitally informed worldview in a century of digitization-and it is an inclusive worldview. I should say that the alphabet is a digital system because any and every human language is a digital system. Any and every language is composed of sounds (phonemes) that are combined into prefixes, suffixes, word roots, words, sentences, and entire stories. In turn, languages are digital systems because they are part of culture, and cultures more generally are digital systems: music is composed of musical notes, art is composed of artistic motives, feelings and complex personal experiences are composed of more basic emotions; and urban environments are composed of architectural types. When we study the universe, genetics, languages, and cultures, we find multiple, nested digital systems. These digital systems are like matryoshkas, or like sets of parentheses one nested in the other. Everyone and everything is part of this world.

I believe that this worldview is particularly useful because it is a scientific worldview. I say a "scientific worldview" because the replicator-mutator-equation is best used in scientific research. Let me provide an example. I said that cities are diverse, and my present example is about cities-I promise.

The replicator-mutator equation has one parameter region for creativity and another for diversification. In their everyday workings, these two parameter regions tend to fall apart. There are phases of creativity, and phases of diversification. During creativity we see growth paired by competitive exclusion; during diversification we see 
recession paired by diversification. I have shown how these phases form cycles of growth and recession in human culture, and it seemed evident to me that these cycles might also be observable in urban space.

\section{Diversification cycles in urban space}

Almost every definition of "city" is about density and diversity, and cities have always been places of diversity: Babel had a tower, but it also had a diversity of languages; Medieval cities had fortifications, but they also had a diversity of guilds; and modern cities have boulevards and electricity, but they also have a diversity of cultures. These examples mention infrastructures, and they mention diversity. However, the infrastructures are changing, while diversity stays. Diversity is the defining characteristic of city. My idea was that this diversity tends to evolve in cycles just like the ones that I had quantified in human culture.

Looking for evidence to test this theory, I found that famous Jane Jacobs has already written, in the 1960s, an entire chapter the "Self-destruction of Diversity" in which she provided empirical observations that match very closely with those things that my theory tells me I should be able to see. Her chapter is part of the book "The Death and Life of Great American Cities," which spurred a flurry of subsequent activism and research.

Once again, my theory says that there are cycles of growth and diversification. The cycles start when sufficient diversity has formed. Diversity attracts people, which leads to growth, but growth comes with competitive exclusion, and competitive exclusion leads to loss of diversity. Yet, when diversity is lost, the initial motivation for growth falls away, and the growth stalls, but then, in absence of growth, diversification can restart. In brief, there are two phases, growth and diversification. Each phase corresponds to a parameter region of the replicator-mutator-equation. As already mentioned, the two parts tend to fall apart, and so we have distinct phases of growth and distinct phases of diversification. Of course, it would be much better to keep the equation together, avoiding the cycles, and building a straight line to success.

Jane Jacobs's observations provide a first empirical proof that cycles of diversification actually exist in urban space. However, I wished more proofs. I wished more quantitative and more up-to-date evidence. With one of my students, Callum Birchall, I developed a method to quantify urban diversity. I felt that, given that cities are defined as places of diversity, such a method would be immensely useful. We succeeded in demonstrating how easy it actually is to create maps of urban diversity, and we validated our results through historical evaluation. For me, this was the method to go. We were able to put diversity onto the map.

Another of my students, Diana Della Pietra, then marked interest in studying diversification in a longitudinal study. We looked at a historical quarter "Sassi" in the city of Matera. Using historical records, we quantified urban activity over the last few decades, and we were able to once again validate our results. Now that we know that our maps are good estimates of diversity, we are ready to interpret our observations. 
What we see is a history that shows how cities naturally run through cycles of diversification, and how the population attempts to limit the rather detrimental effects of the cycles through legislation.

Here's the story we found: Since the 1980s, our maps show that Sassi has diversified. Already a diverse and polycentric neighborhood since times immemorial, Sassi has grown even more diverse through the introduction of new types of activity, in particular those related to tourism. In the 1990s, Sassi became UNESCO world heritage, and in 2019, Matera, the city where Sassi is located, became European Capital of Culture.

Along the way, hospitality has become the most lucrative type of urban activity, which led to a dramatic increase in hotels. Eventually, the city figured that it had to protect the neighborhood by limiting the expansion of hotels, formally, through legislation. Diana and my work shows that this legislation has come just in time to level unwanted cycles of diversification. We can show that, if the number of hotels were to double once again, it would lead to loss of diversity.
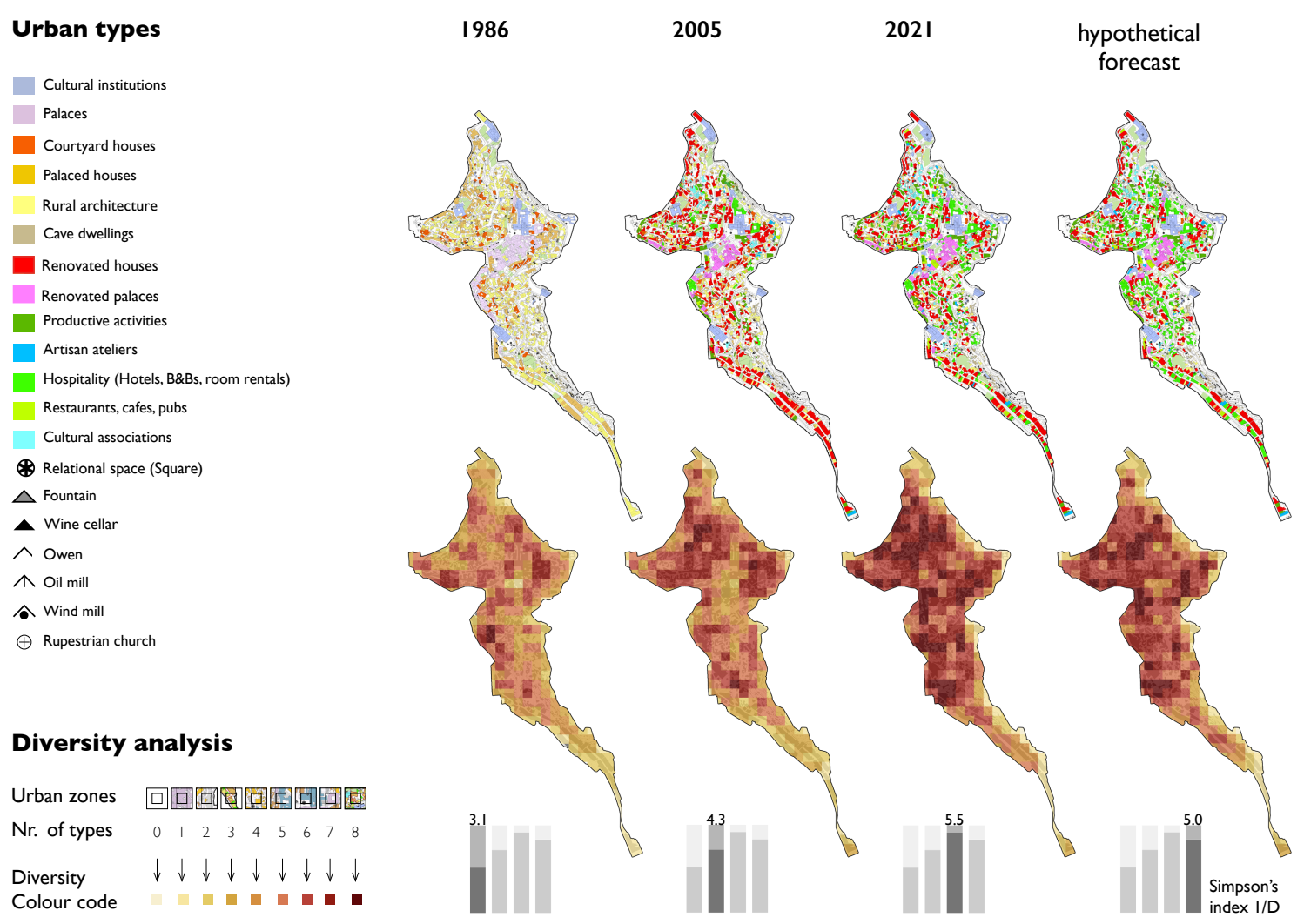

\section{Diversity analysis}

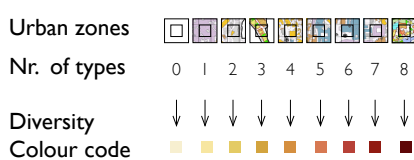

Figure 2. Diversity maps of Sassi. Since 1986, urban diversity has increased. In parallel, Sassi has become UNESCO heritage in 1993, and Matera was European cultural capital in 2019. As can be seen in the first three maps, the introduction of new types of urban activity related to tourism has initially led to diversification. However, further expansion of tourism may lead to a loss in urban diversity as tourism would keep outcompeting other activities. We make a hypothetical forecast of what would happen to urban diversity if the number of hotels doubled once again. Diversity would decrease. 
The story that we quantified is easily understood. Hotel speculation would lead to rising prices, benefiting many, but hotels would outcompete other activities and would lead, as we have demonstrated, to the loss of urban diversity. Eventually, the hotels would become a hospitality bubble that would dominate the urban environment and threaten to burst. In Figure 2, you can see our three historical maps. Note how diversity increases as Sassi advances to UNESCO heritage and to historical center of a cultural capital. The fourth map forecasts the effects of a further doubling in the number of hotels. Each hotel may bring growth, and may have its own creative story to tell. However, growth and creativity limit diversification. Some hotels may go so far and creatively redefine what it means to be a hotel. Nevertheless, hotels are hotels. They are not artisan ateliers, shops, cultural associations, rural or palace housing, etc. Diversity decreases when tourism creatively outcompetes all other urban activity. As you can see, Sassi is on the tipping point between diversification, growth, creativity, and loss of diversity-and the city is working hard to stay there in unstable equilibrium.

\section{Contributions}

Dan C. Baciu has written the article. Diana Della Pietra has studied urban diversity and created the diversity maps of Matera as student under the lead of Dan C. Baciu as Assistant Professor of Digital Tools at TU Delft, Faculty of Architecture and the Built Environment.

\section{Bibliography}

Baciu DC (2015). "Systemic Analysis of Cooperation: Architects, Urban Space and Tourism." JETK 4, 27-30.

Baciu DC (2016). "Sigfried Giedion: Historiography and History of Reception on a Global Stage." Ar(t)chitecture, Haifa: Technion Israel Institute of Technology, 40-52.

Baciu DC (2017). “The Chicago School: Evolving Systems of Value.” Report, HathiTrust Research Center.

Baciu DC (2018). "From Everything Called Chicago School Towards the Theory of Varieties." Doctoral dissertation, Illinois Institute of Technology.

Baciu DC (2019). "The Chicago School: Large-Scale Dissemination and Reception." Prometheus $2,20-41$.

Baciu DC (2020). "Cultural Life: Theory and Empirical Testing.” Biosystems 197.104208.

Baciu DC (2021). "Is "Cultural Life" a Form of Life?" Lecture, TU Delft, published in: Igloo Feb. 2021, 58-61.

Baciu DC, Birchall C (2021). "Mapping Diversity: From Ecology and Human Geography to Urbanism and Culture." OSF preprints.

Baciu DC, Della Pietra D (2021). "Diversification Cycles in Urban Enironments: Evidence from Sassi, UNESCO world heritage site, Italy." OSF preprints.

Jacobs J, "The self-destruction of diversity," Death and Life of Great American Cities. New York: Random House, 1961: 241-257.

Page K, Nowak MA (2002). “Unifying Evolutionary Dynamics.” J. theor. Biol. 219, 93-98. 


\section{Digitalizare, creativitate și diversificare: o viziune științifica urmată de o aplicație în arhitectură și urbanism}

\section{Autori}

Dan C. Baciu, Diana Della Pietra.

Faculty of Architecture and the Built Environment, TU Delft, Delft, Olanda.

\section{Digitalizare, creativitate și diversificare}

A, B, C, ... există vreo treizeci de litere în alfabet, mai mult de un milion în această revistă, iar un număr necunoscut de mare, poate catralioane de litere, care au fost scrise de când a fost inventat alfabetul, acum doar cam trei mii de ani în urmă. La început, alfabetul era o mână de simboluri, unele drepte, altele curbe. Între timp, a devenit o lume de nelimitate posibilități.

Povestea acestor linii drepte-curbe, nu e un banc, dar are un fel de poantă. Alfabetele timpurii erau zimțate. Aveau multe linii drepte și puține curbe. Dar literele latine au o distribuție mult mai uniformă de linii drepte și curbe. Aproximativ jumătate din litere sunt compuse din linii drepte, în timp ce cealaltă jumătate conțin și linii curbe. Am putea decide să înlocuim liniile curbe fiecare cu câte un zero, iar liniile drepte fiecare cu câte un unu; și am rescrie atunci toate literele din alfabet cu doar doua simboluri, zero și unu. Ei bine, atunci am obține un alfabet, tocmai cum am spus, numai și numai din zero si unu, care - ce surpriză - este ca un cod digital de computer. Codurile computerului sunt coduri scrise în zero și unu. Pe parcursul timpului, alfabetul a devenit tot mai digital.

Unii oameni consideră computerele ca fiind ceva riguros. Ele nu pot face erori. În realitate, computerele nu pot fi separate de oameni. Exact acest fapt le face de-a dreptul puternice. Computerele si oamenii au ceva foarte clar in comun: codul digital. Iar sistemele digitale precum alfabetul și codul computerelor $0 / 1$ au o caracteristică cu adevărat uimitoare. Aceasta este caracteristica pe care am observat-o deja. Cu doar o mână de simboluri, sistemele digitale creează lumi cu nenumărate posibilități. Este ușor de înțeles. Cu doar degetele de la o mână (cuvântul „digital” vine de la „degete”), se poate număra si număra la infinit, fără o singură repetiție. Această caracteristică deschide căi către creativitate și diversitate.

Poate că acest fenomen, și anume că sistemele digitale deschid căi către creativitate și diversitate, se regăsește cel mai evident în codul genetic. Cu doar două perechi de baze genetice - una am putea decide să o numim 0 și cealaltă 1 - codul genetic codifică orice informație genetică. S-au scris nenumărate, nenumărabile miliarde de miliarde 
de perechi de baze genetice de la începutul vieții pe pământ-și tot nu ne-am obosit de viață. Creativitatea și diversitatea vieții biologice vor convinge pe oricine că sistemele digitale, chiar si cele binare in $0 / 1$ au un potențial nelimitat.

Figura 1. Fiecare idee care se naște este produsul tuturor ideilor culturii din trecut, creativitate și diversificare. Din punct de vedere tehnic, termenul $q_{i j}$ stă pentru orice matrice de creativitate, mutații genetice, sau asocieri mentale. Termenul $f_{i}(\mathrm{x})$ stă pentru interacțiuni între variante.

Dar poanta 0/1 continuă. Perechile de baze genetice și proteinele care le simbolizează sunt toate molecule, care sunt combinații de atomi. Acești atomi, când vine vorba de tipul și proprietățile lor, sunt determinați de nucleele lor, care sunt combinații de protoni și neutroni. La rândul lor, protonii și neutronii sunt combinații de Quarks. Există doar două tipuri de Quarks: up și down. Am putea decide să-i numim 0 și 1. Universul în care trăim este un univers digital. Acest univers digital a deschis posibilități infinite care se explorează prin creativitate și diversificare. Gândiți-vă cât de diverse sunt ecosistemele și orașele. Sunt oaze de diversitate.

În articolul meu anterior din Igloo, am vorbit despre ecuația „replicator-mutatorequation”, dar n-am arătat ecuația. De data aceasta, aș vrea să fac asta. Puteți vedea ecuația, adnotată jucăuș în Figura 1. Ecuația afirmă că noua cultură este reproducerea culturii din trecut, transformată prin creativitate și interacțiuni. Interacțiunile intre variantele culturale sunt foarte importante, deoarece ele duc la diversificare. Mi-am luat libertatea de a scrie: Cultura nouă este reproducerea culturii din trecut, transformată de creativitate și de diversificare.

Permiteți-mi acum să explic de ce această ecuație merge mână în mână cu sistemele digitale. În primul rând, sistemele digitale încep, cum am observat deja, cu doar o mână de simboluri. Această economie de mijloace ușurează reproducerea-iar reproducerea face parte din ecuație. Cut cât mai simplă e reproducerea, cu atât mai bine. În al doilea rând, sistemele digitale permit ca simbolurile digitale să fie combinate și recombinate in mod creativ. Iar și creativitatea e parte din ecuație. În sfârșit, sistemele digitale deschid posibilități nelimitate. Diversificarea este necesară pentru a explora pe larg ceea ce este posibil. De exemplu, pentru a explora unde duce oceanul, este nevoie de mai multe nave pentru a naviga în mai multe direcții. Acesta este un mod metaforic de a explica diversificarea. Diversificarea este necesară atunci când se explorează lumi de nelimitate posibilități. Este evident, deci-dacă evoluția avansează prin reproducere, creativitate, și diversificare-acestea ar trebui să ducă la crearea multor sisteme digitale prin care se explorează posibilitățile nemărginite al universului in care trăim. Iar asta este exact ceea ce am observat adineaori. Trăim într-un univers digital.

Pentru mine, această perspectivă este o viziune asupra lumii, poate o filozofie de viață. Este o viziune asupra lumii informată de digitalizare într-un secol de digitalizare - și este o viziune incluzivă, care corespunde pentru oricine și oriunde. Ar trebui să spun că alfabetul este un sistem digital, deoarece orice limbă umană este un 
sistem digital. Orice limbă este compusă din sunete (foneme) care sunt combinate în prefixe, sufixe, rădăcini de cuvinte, cuvinte, propoziții și întregi narative. De la sunete la povesti avem mai multe sisteme digitale, îmbinate. Sunt ca faimoasele Matrioșca, sau ca un sistem de paranteze, una continuând in cealaltă. Așadar limbile sunt sisteme digitale, deoarece fac parte din cultură, iar culturile, în general, sunt sisteme digitale: muzica este compusă din note muzicale, arta este compusă din motive artistice, experiențele si trăirile sunt compuse din emoții; iar spațiile urbane sunt compuse din tipuri arhitecturale.

Cred că această viziune asupra lumii este deosebit de utilă, deoarece este o viziune științifică. Spun o „viziune științifică”, deoarece ecuația de adineaori poate fi utilizată în cercetarea științifică. Permiteți-mi să vă ofer un exemplu. Am spus că orașele sunt diverse. Vă propun deci un exemplul despre orașe - promit.

Ecuația replicator-mutator are o regiune de parametri pentru creativitate și alta pentru diversificare. În funcționarea lor de zi cu zi, aceste două regiuni parametrice tind să acționeze independent una de cealaltă. Există perioade de creativitate și perioade de diversificare. Ecuația combina creativitatea cu creștere, iar diversificarea cu recesiune. Într-un articol anterior, am arătat cum aceste faze formează cicluri de creștere și recesiune în cultura umană - și mi s-a părut evident că aceste cicluri ar trebui să fie observabile și în spațiul urban.

\section{Cicluri de diversificare în spațiul urban}

Aproape fiecare definiție a cuvântului „oraș” se referă la densitate și diversitate. Orașele au fost întotdeauna centre de diversitate: Babel avea un turn, dar avea și o uluitoare diversitate lingvistică; orașele medievale aveau fortificații, dar aveau și o mare diversitate de bresle; iar orașele moderne au bulevarde și electricitate, dar au și o faimoasa diversitate culturală. Aceste exemple menționează infrastructuri și menționează diversitate. Infrastructurile nu definesc orașul, fiindcă se schimbă. Constanta definitorie care rămâne este diversitatea. Ideea mea a fost că această diversitate tinde să evolueze în cicluri la fel ca cele pe care le cuantificasem în cultura umană.

Căutând dovezi pentru a testa această teorie, am constatat că celebra Jane Jacobs a scris deja, în anii 1960, un întreg capitol „Autodistrugerea diversității” în care descrie observații care se potrivesc bine cu previziunile mele teoretice. Capitolul ei face parte din cartea „Moartea și viața marilor orașe americane”, care a stimulat o explozie de activism și cercetare.

Deci, predicția mea este că exista cicluri de creștere si diversificare. Ciclurile încep atunci când s-a format suficientă diversitate. Diversitatea atrage oamenii, ceea ce duce la creștere, dar creșterea aduce excludere prin competiție, iar această excludere duce la pierderea diversității. Însă, odată ce diversitatea se pierde, motivația inițială pentru creștere scade. Creșterea se oprește. Dar deîndată ce creșterea se oprește, diversificarea se poate relua. Pe scurt, există două faze, creșterea și diversificarea. Fiecare fază corespunde unei regiuni parametrice distincte in replicator-mutator- 
equation. Cum am precizat anterior, cele două regiuni parametrice tind să acționeze independent una de cealaltă. Desigur, ar fi mult mai bine să acționeze simultan. Am avansa în linie dreaptă către succes.

Observațiile lui Jane Jacobs oferă o primă dovadă empirică că ciclurile de diversificare există în spațiul urban. Cu toate acestea, mi-am dorit mai multe dovezi. În special, miam dorit mai multe dovezi cantitative și din ziua de astăzi. $\mathrm{Cu}$ unul dintre studenții mei, Callum Birchall, am dezvoltat o metodă de cuantificare a diversității urbane. Am presupus că, având în vedere că orașele sunt definite ca centre ale diversității, o astfel de metodă ar fi extrem de utilă. Am lucrat la această metodă, si am reușit să demonstrăm de fapt cât de ușor este să creezi hărți ale diversității urbane. Apoi am validat rezultatele prin evaluare istorică. Pentru mine, aceasta a fost metoda de urmat.

In acel moment, o studentă, Diana Della Pietra, și-a manifestat interesul să studieze diversitatea urbană într-un studiu longitudinal. Am ales pentru acest studiu un cartier istoric „Sassi” în orașul Matera. Folosind harți istorice, am cuantificat activitatea urbană în ultimele decenii și am reușit să validăm din nou rezultatele prin evaluare istorică. Ceea ce vedem este o poveste despre viața orașelor, cum Jane Jacobs ar fi visat. Vedem cum orașele trec prin cicluri naturale de diversificare și cum populația încearcă să limiteze, prin legislație, efectele destul de dăunătoare ale acestor cicluri.

Iată povestea pe care am găsit-o: Din anii 1980, hărțile noastre arată că Sassi s-a diversificat. Deja un cartier divers și policentric din timpuri imemoriale, Sassi a devenit și mai divers după ce noi tipuri de activitate au fost introduse, în special cele legate de turism. În anii 1990, Sassi a devenit patrimoniu mondial UNESCO, iar în 2019, Matera, orașul în care se află Sassi, a devenit capitală culturală europeană.

Între timp, cel mai profitabil tip de activitate urbană a devenit turismul. Acest fapt bine cunoscut de investitori a dus la o creștere dramatică a numărului de hotele. În cele din urmă, locatarii și-au dat seama că trebuie să protejeze cartierul limitând extinderea hotelurilor, formal, prin legislație. Lucrarea mea si a Dianei arată că această legislație a venit la timp potrivit pentru a stabili oscilările nedorite între diversificare si creștere. Putem arăta că, dacă numărul hotelurilor s-ar dubla din nou, ar duce la pierderea diversității.

Povestea pe care am cuantificat-o este ușor de înțeles. Speculațiile hotelierilor duc la creșterea prețurilor, dar creșterea ar duce la formarea unui ciclu în care diversitatea s-ar pierde. În Figura 2, puteți vedea cele trei hărți istorice pe care le-am creat. Observați cum diversitatea crește intre 1986 si 2021. A patra hartă este o simulație. Prevede efectele unei dublări suplimentare a numărului de hotele. Poate că creativitatea umana ar duce la multe hotele diferite. Cu toate astea, tot hotele rămân. Ele nu devin ateliere, magazine, asociați culturale, etc. Diversitatea ar scade dacă turismul ar înlătura prea multe alte activități urbane. După cum puteți vedea, Sassi este la un punct critic între diversificare, creștere, creativitate, și pierdere a diversității - iar orașul încearcă din greu să a rămână în acest echilibru instabil. 
Figura 2. Hărți de diversitate urbană în Sassi. Din 1986, diversitatea urbană a crescut. În paralel, Sassi a devenit patrimoniu UNESCO în 1993, iar Matera a fost capitală culturală europeană în 2019. Introducerea de noi tipuri de activități urbane legate de turism a dus inițial la o diversificare suplimentară, fată de 1986. Cu toate acestea, extinderea în continuare a turismului poate duce în prezent la o pierdere a diversității urbane, deoarece turismul ar continua să concureze cu alte activități. Ultima hartă este o prognoză ipotetică a ceea ce s-ar întâmpla cu diversitatea urbană dacă numărul hotelurilor s-ar dubla din nou. Diversitatea ar scădea dramatic.

\section{Contributii}

Dan C. Baciu a scris articolul. Diana Della Pietra a studiat diversitatea urbană și a creat hărțile diversității pentru Sassi ca student sub conducerea lui Dan C. Baciu în calitate de profesor asistent la TU Delft, Faculty of Architecture and the Built Environment.

\section{Bibliografie}

Baciu DC (2015). "Systemic Analysis of Cooperation: Architects, Urban Space and Tourism." JETK 4, 27-30.

Baciu DC (2016). "Sigfried Giedion: Historiography and History of Reception on a Global Stage." Ar(t)chitecture, Haifa: Technion Israel Institute of Technology, 40-52.

Baciu DC (2017). “The Chicago School: Evolving Systems of Value.” Report, HathiTrust Research Center.

Baciu DC (2018). "From Everything Called Chicago School Towards the Theory of Varieties." Doctoral dissertation, Illinois Institute of Technology.

Baciu DC (2019). "The Chicago School: Large-Scale Dissemination and Reception.” Prometheus $2,20-41$.

Baciu DC (2020). "Cultural Life: Theory and Empirical Testing.” Biosystems 197.104208.

Baciu DC (2021). "Is "Cultural Life" a Form of Life?" Lecture, TU Delft, published in: Igloo Feb. 2021, 58-61.

Baciu DC, Birchall C (2021). "Mapping Diversity: From Ecology and Human Geography to Urbanism and Culture." OSF preprints.

Baciu DC, Della Pietra D (2021). "Diversification Cycles in Urban Enironments: Evidence from Sassi, UNESCO world heritage site, Italy." OSF preprints.

Jacobs J, "The self-destruction of diversity," Death and Life of Great American Cities. New York: Random House, 1961: 241-257.

Page K, Nowak MA (2002). “Unifying Evolutionary Dynamics.” J. theor. Biol. 219, 93-98. 